\title{
Lignans from the Fruits of Melia toosendan and Their Agonistic Activities on Melatonin Receptor $\mathrm{MT}_{1}$
}

\author{
Authors \\ Hao Wang ${ }^{1,2}$, Chang-An Geng ${ }^{1}$, Hong-Bo Xu ${ }^{1,2}$, Xiao-Yan Huang ${ }^{1}$, Yun-Bao Ma ${ }^{1}$, Cai-Yan Yang ${ }^{1,2}$, \\ Xue-Mei Zhang ${ }^{1}$, Ji-Jun Chen ${ }^{1}$ \\ Affiliations \\ ${ }^{1}$ State Key Laboratory of Phytochemistry and Plant Resources in West China, Kunming Institute of Botany, \\ Chinese Academy of Sciences, Kunming, P. R. China \\ 2 University of Chinese Academy of Sciences, Beijing, P. R. China
}

Key words
- Melia toosendan
- Meliaceae
lignans
- $\mathrm{MT}_{1}$ receptor
agonistic activity

received Dec. 5, 2014

revised March 11, 2015

accepted April 22, 2015

\section{Bibliography}

DOI http://dx.doi.org/

10.1055/s-0035-1546127

Published online June 17, 2015

Planta Med 2015; 81: 847-854

(C) Georg Thieme Verlag KG

Stuttgart · New York .

ISSN 0032-0943

\section{Correspondence}

Prof. Ji-Jun Chen

State Key Laboratory of

Phytochemistry and Plant

Resources in West China

132 Lanhei Road

Kunming 650201

P. R. China

Phone: + 8687165223265

Fax: + 8687165227197

chenjj@mail.kib.ac.cn

\section{Abstract \\ $\nabla$}

Investigation on the fruits of Melia toosendan afforded seven new lignans (1-7), along with seventeen known compounds (8-24). The structures of the new compounds, involving four neo-lignans (1-4), two sesquilignans (5-6), and a norlignan (7), were elucidated based on extensive spectroscopic analyses (high-resolution electro-

\section{Introduction}

\section{$\nabla$}

The fruit of Melia toosendan Sieb. et Zucc. (Meliaceae), well-known as "Chuan-Lian-Zi" in Chinese, is an important traditional Chinese medicine (TCM) for the treatment of malaria, sting, stomachache, acute or chronic inflammations, and parasitosis [1-3], and possesses the property of "soothing liver-qi stagnation", indicating the neuroprotective potency according to TCM theory [4]. Pharmacological studies have demonstrated that toosendanin is an active component of "ChuanLian-Zi" as a selective presynaptic blocker, effective antibotulismic agent, and proliferation inhibitor of various human cancer cells $[1,5]$. In addition, "Chuan-Lian-Zi" is widely used as a botanical pesticide in agriculture due to the presence of limonoid-type triterpenoids $[3,6]$.

Previous research has mainly focused on the limonoid-type triterpenoids of $M$. toosendan, from which more than 50 cases have been isolated $[3,7$, 8]. However, there have been only a few investigations of lignans, another main component of "Chuan-Lian-Zi". Lignans as secondary metabolites derived from the shikimic acid pathway are widely distributed in plants and possess antitumor, antimitotic, antiviral, enzyme inhibitory, piscicidal, and antifungal activities [9-11]. Especially, it has been reported that lignans have neuroprotective activity in vitro and in vivo [12-15]. spray ionization mass spectra, ultraviolet, infrared, one-dimensional and two-dimensional nuclear magnetic resonance). Compound 24 exhibited activity on melatonin receptor type 1 with an agonistic rate of $57.77 \%$ at $1.02 \mathrm{mM}$ according to the assay on HEK293 cell lines in vitro.

Supporting information available online at http://www.thieme-connect.de/products
Melatonin receptor type $1\left(\mathrm{MT}_{1}\right)$, a high-affinity $\mathrm{G}$-protein-coupled receptor widely distributed in the brain, retina, cardiovascular system, immune system, reproductive system, kidneys, pancreas, and liver, is a very important target in the treatment of most melatonin-related nervous system diseases, including sleep disorders, depression, and anxiety syndromes [16-18]. Mediation on the activation of $\mathrm{MT}_{1}$ is an effective therapy for these psychiatric problems, based on which several agonistic drugs (circadin, ramelteon, agomelatine, etc.) have been developed successfully, along with many potential candidates undergoing clinical trials [18].

In order to clarify the neuroprotective components of the entitled plant, the bioassay-guided investigation on the EtOAc part of the fruit of $M$. toosendan led to the isolation of seven new lignans (1-7; ○ Fig. 1) and seventeen known ones (8-24; Fig. 1S, Supporting Information). Among them, compounds $\mathbf{8 - 2 3}$ were isolated from the fruits of $M$. toosendan for the first time. Their structural elucidation and biological evaluation are reported in this paper.

\section{Results and Discussion}

$\nabla$

Compound 1 showed a quasi-molecular ion peak at $m / z 425.1585[\mathrm{M}+\mathrm{Na}]^{+}$in the positive HRESIMS, indicating a molecular formula of $\mathrm{C}_{22} \mathrm{H}_{26} \mathrm{O}_{7}$ 


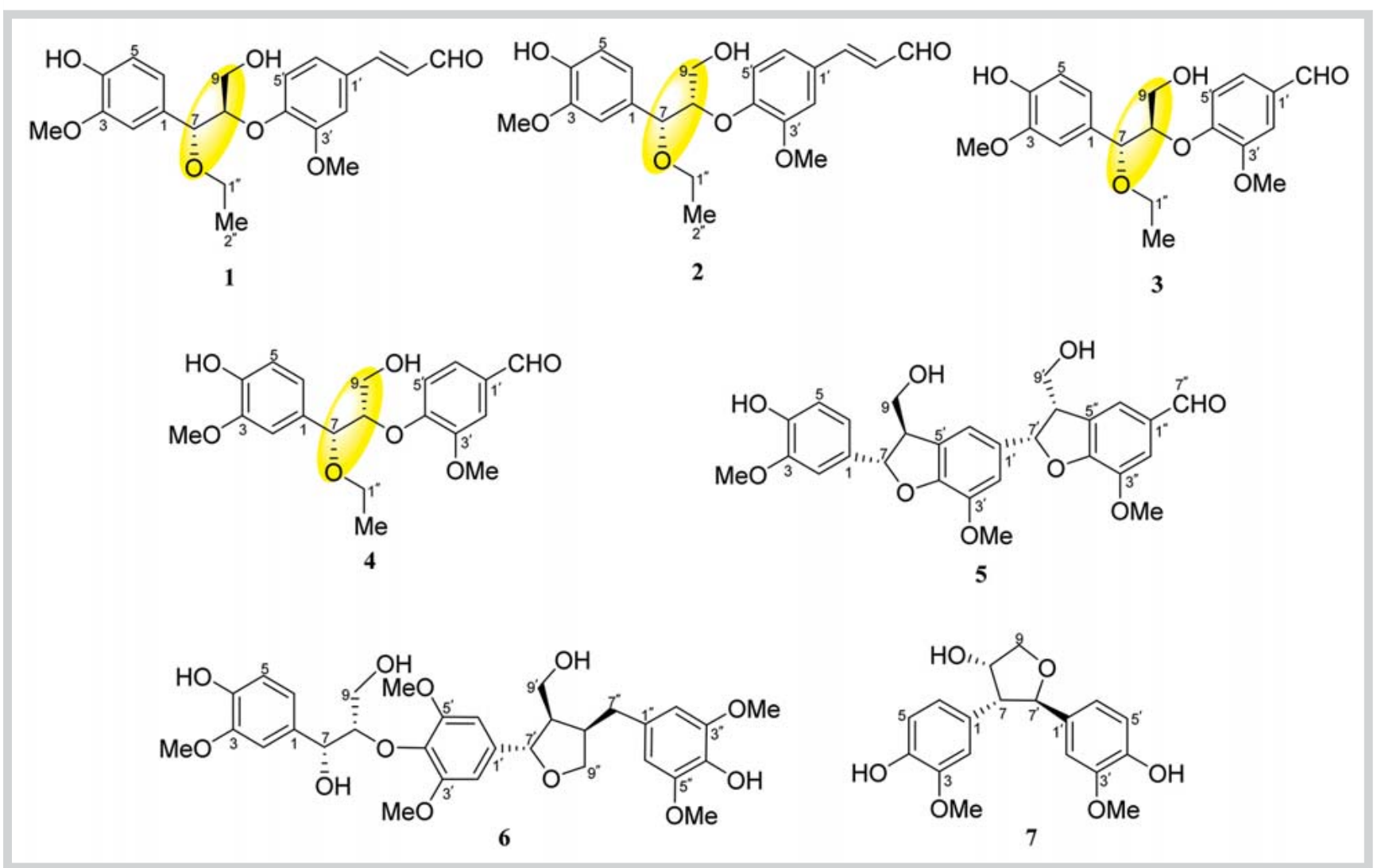

Fig. 1 The structures of compounds 1-7. (Color figure available online only.)

with ten degrees of unsaturation. Its IR spectrum suggested the groups of hydroxyl $\left(3428 \mathrm{~cm}^{-1}\right), \alpha, \beta$-unsaturated carbonyl $\left(1666 \mathrm{~cm}^{-1}\right)$, aromatic rings $\left(1597,1511\right.$, and $\left.1460 \mathrm{~cm}^{-1}\right)$, and ether bonds $\left(1273,1130\right.$, and $\left.1033 \mathrm{~cm}^{-1}\right)$. The ${ }^{1} \mathrm{H}$ NMR spectrum showed an ethoxy group at $\delta 3.41(1 \mathrm{H}, \mathrm{dq}, J=9.5,7.2 \mathrm{~Hz}), 3.36$ $(1 \mathrm{H}, \mathrm{dq}, J=9.5,7.2 \mathrm{~Hz})$, and $1.14(3 \mathrm{H}, \mathrm{t}, J=7.2 \mathrm{~Hz})$, two methoxy groups at $\delta 3.80(3 \mathrm{H}, \mathrm{s})$ and $3.77(3 \mathrm{H}, \mathrm{s})$, and six aromatic protons in two ABX spin systems, $\delta 6.94(1 \mathrm{H}, \mathrm{d}, J=1.8 \mathrm{~Hz}), 6.69(1 \mathrm{H}, \mathrm{d}$, $J=8.1 \mathrm{~Hz})$, and $6.80(1 \mathrm{H}, \mathrm{dd}, J=8.1,1.8 \mathrm{~Hz})$, and $\delta 7.18(1 \mathrm{H}, \mathrm{d}$, $J=1.9 \mathrm{~Hz}), 6.95(1 \mathrm{H}, \mathrm{d}, J=8.4 \mathrm{~Hz})$, and $7.12(1 \mathrm{H}, \mathrm{dd}, J=8.4$, $1.9 \mathrm{~Hz}$ ), suggesting the presence of two 1,3,4-trisubstituted phenyl rings. The signals at $\delta 9.56(1 \mathrm{H}, \mathrm{d}, J=7.8 \mathrm{~Hz}), 7.54(1 \mathrm{H}, \mathrm{d}$, $J=15.8 \mathrm{~Hz}$ ), and $6.64(1 \mathrm{H}, \mathrm{dd}, J=15.8,7.8 \mathrm{~Hz}$ ) were owed to a conjugated formyl group with a trans-form double bond. Its ${ }^{13} \mathrm{C} \mathrm{NMR}$ (DEPT) spectrum was similar with that of threo-guaiacylglycerol$\beta$-coniferyl aldehyde ether (15) [19] except for the additional ethoxy group and the obvious downfield shift of C-7 from $\delta_{\mathrm{C}}$ 73.4 to 82.5 , suggesting that 1 was the 7-O-ethyl derivative of 15. This deduction was supported by the correlations of $\delta_{\mathrm{H}} 4.46$ $(\mathrm{H}-7) / \delta_{\mathrm{C}} 65.6\left(\mathrm{C}-1^{\prime \prime}\right)$ and $\delta_{\mathrm{H}} 3.41,3.36\left(\mathrm{H}-1^{\prime \prime}\right) / \delta_{\mathrm{C}} 82.5(\mathrm{C}-7)$ in the HMBC spectrum (๑ Fig. 2). Previous reports revealed that compounds with a threo-guaiacylglycerol unit could be distinguished from its erythro isomer with the chemical shifts of $\mathrm{C}-8$ and the ${ }^{3} J_{\mathrm{H}, \mathrm{H}}$ coupling constants of the $\mathrm{H}-7 / \mathrm{H}-8$ protons. The chemical shifts of C-8 in the threo-form were slightly lower than its erythro isomer, and the $J_{7,8}$ value in the threo-form was larger than the erythro-form [20-24]. Thus, the threo-configuration of the C-7/ C-8 system was indicated by the $J_{7,8}$ value of $7.1 \mathrm{~Hz}$, and compound 1 was assigned as threo-guaiacylethoxyglycerol- $\beta-O-4^{\prime}-$ coniferyl aldehyde ether.
Compound 2 had a molecular formula of $\mathrm{C}_{22} \mathrm{H}_{26} \mathrm{O}_{7}$ based on the positive HRESIMS at $m / z 425.1589[\mathrm{M}+\mathrm{Na}]^{+}$. It was proposed to be the isomer of 1 due to their similar ${ }^{1} \mathrm{H}$ NMR and ${ }^{13} \mathrm{C}$ NMR (DEPT) spectral data. Detailed analyses of its ${ }^{1} \mathrm{H}-{ }^{1} \mathrm{H}$ COSY and HMBC spectra verified that compound 2 possessed the same planar structure with 1. The upfield shift of $\mathrm{H}-9$ from $\delta 3.86(1 \mathrm{H}, \mathrm{dd}$, $J=9.6,3.7 \mathrm{~Hz}, \mathrm{H}-9 \mathrm{a})$ and $3.84(1 \mathrm{H}, \mathrm{dd}, J=9.6,5.7 \mathrm{~Hz}, \mathrm{H}-9 \mathrm{~b})$ in compound 1 to $\delta 3.67(1 \mathrm{H}$, dd, $J=10.4,3.1 \mathrm{~Hz}, \mathrm{H}-9 \mathrm{a})$ and 3.49 $(1 \mathrm{H}, \mathrm{dd}, J=10.4,4.3 \mathrm{~Hz}, \mathrm{H}-9 \mathrm{~b})$ in 2 , along with the upfield shift of $\mathrm{C}-8$ from $\delta_{\mathrm{C}} 85.3$ in $\mathbf{1}$ to 84.6 in 2, suggested the changes of the stereochemistry. In contrast to the $J_{7,8}$ value of $7.1 \mathrm{~Hz}$ in $\mathbf{1}$, the obvious small value of $4.2 \mathrm{~Hz}$ suggested the erythro-configuration [20-24]. Therefore, compound 2 was characterized as er$y$ thro-guaiacylethoxyglycerol- $\beta$ - 0 - 4 '-coniferyl aldehyde ether. Compound 3 was determined to be $\mathrm{C}_{20} \mathrm{H}_{24} \mathrm{O}_{7}$ on the basis of the positive HRESIMS at $m / z 399.1435[\mathrm{M}+\mathrm{Na}]^{+}$. Its ${ }^{1} \mathrm{H}$ - and ${ }^{13} \mathrm{C}-\mathrm{NMR}$ data ( Tables 1 and $\mathbf{3}$ ) were similar with those of compound $\mathbf{1}$, except for the absence of two vinylic carbons and the upfield shift of the aldehyde group from $\delta_{\mathrm{C}} 196.1$ in 1 to 192.9 in 3, which suggested the aldehyde group was directly linked to $\mathrm{C}-1$ '. This deduction was confirmed by HMBC correlations ( Fig. 2) from $\delta_{\mathrm{H}}$ $9.73\left(\mathrm{H}-7^{\prime}\right)$ to $\delta_{\mathrm{C}} 111.5\left(\mathrm{C}-2^{\prime}\right)$ and $127.2\left(\mathrm{C}-6^{\prime}\right)$. The threo-configuration was indicated by the $J_{7,8}$ value of $7.1 \mathrm{~Hz}$. Thus, compound 3 was elucidated as threo-guaiacylethoxyglycerol- $\beta-0$-4'-guaiacyl aldehyde ether.

Compound 4 had a quasi-molecular ion peak at $m / z$ 399.1405 [M $+\mathrm{Na}]^{+}$(calcd. for 399.1414) in HRESIMS, suggesting a molecular formula of $\mathrm{C}_{20} \mathrm{H}_{24} \mathrm{O}_{7}$ with nine degrees of unsaturation. Comparing the ${ }^{1} \mathrm{H}$ NMR and ${ }^{13} \mathrm{C}$ NMR (DEPT) spectral data with those of compound 3, the upfield shift of $\mathrm{H}-9$ from $\delta 3.89$ ( $1 \mathrm{H}, \mathrm{dd}, J=11.4$, 


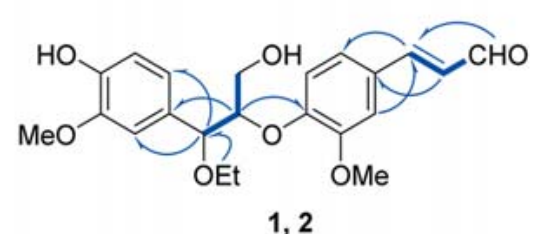

1,2<smiles>CCOC12CC3CC1(Cc1cc(OC)c(O)cc13)C(O)c1cc(c(OC)c(CCO)c1OC)O2</smiles>

3,4

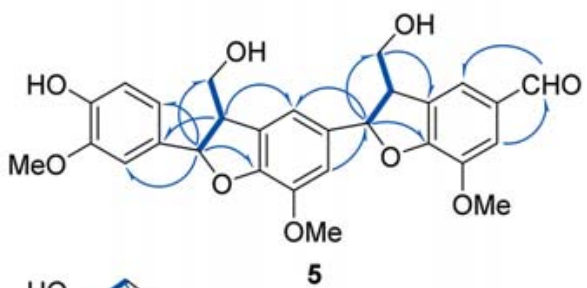

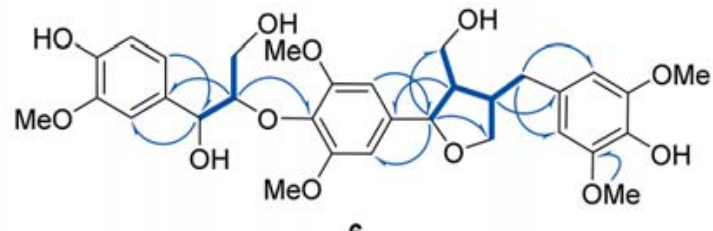

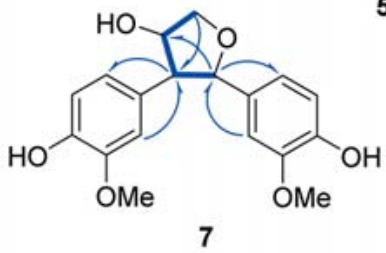

$-\mathrm{H}-\mathrm{H}$ COSY $\rightarrow \mathrm{HMBC}$

Fig. 2 The key ${ }^{1} \mathrm{H}-{ }^{1} \mathrm{H}$ COSY and $\mathrm{HMBC}$ correlations of compounds $\mathbf{1 - 7}$. (Color figure available online only.)

Table 1 ' $\mathrm{H}$-NMR (600 MHz) data for compounds 1-4 in $\mathrm{CD}_{3} \mathrm{OD}(\delta$ in ppm, $J$ in $\mathrm{Hz})$.

\begin{tabular}{|c|c|c|c|c|}
\hline No. & 1 & 2 & 3 & 4 \\
\hline 2 & $6.94 d(1.8)$ & $6.96 \mathrm{~d}(1.8)$ & $6.94 d(1.8)$ & $6.96 d(1.7)$ \\
\hline 5 & $6.69 \mathrm{~d}(8.1)$ & $6.76 \mathrm{~d}(8.1)$ & $6.67 d(8.0)$ & $6.75 d(8.0)$ \\
\hline 6 & $6.80 \mathrm{dd}(8.1,1.8)$ & $6.80 \mathrm{dd}(8.1,1.8)$ & $6.80 \mathrm{dd}(8.0,1.8)$ & $6.81 \mathrm{dd}(8.0,1.7)$ \\
\hline 7 & $4.46 \mathrm{~d}(7.1)$ & $4.52 \mathrm{~d}(4.2)$ & $4.46 \mathrm{~d}(7.1)$ & $4.53 d(4.5)$ \\
\hline 8 & $4.54 \mathrm{ddd}(7.1,5.7,3.7)$ & $4.51 \mathrm{ddd}(4.3,4.2,3.1)$ & 4.64 ddd $(7.1,5.7,3.6)$ & $4.62 \operatorname{ddd}(6.2,4.5,3.5)$ \\
\hline $9 a$ & $3.86 \mathrm{dd}(9.6,3.7)$ & $3.67 \mathrm{dd}(10.4,3.1)$ & $3.89 \mathrm{dd}(11.4,3.6)$ & $3.68 \mathrm{dd}(12.0,3.5)$ \\
\hline $9 b$ & $3.84 \mathrm{dd}(9.6,5.7)$ & $3.49 \mathrm{dd}(10.4,4.3)$ & $3.85 \mathrm{dd}(11.4,5.7)$ & $3.53 \mathrm{dd}(12.0,6.2)$ \\
\hline $2^{\prime}$ & $7.18 \mathrm{~d}(1.9)$ & $7.28 \mathrm{~d}(1.9)$ & $7.35 \mathrm{~d}(1.9)$ & $7.45 \mathrm{~d}(1.8)$ \\
\hline $5^{\prime}$ & $6.95 d(8.4)$ & $7.08 \mathrm{~d}(8.4)$ & $7.07 \mathrm{~d}(8.3)$ & $7.19 \mathrm{~d}(8.1)$ \\
\hline $6^{\prime}$ & $7.12 \mathrm{dd}(8.4,1.9)$ & $7.19 \mathrm{dd}(8.4,1.9)$ & $7.38 \mathrm{dd}(8.3,1.9)$ & $7.46 \mathrm{dd}(8.1,1.8)$ \\
\hline $7^{\prime}$ & $7.54 \mathrm{~d}(15.8)$ & $7.59 \mathrm{~d}(15.8)$ & $9.73 \mathrm{~s}$ & $9.78 \mathrm{~s}$ \\
\hline $8^{\prime}$ & $6.64 \mathrm{dd}(15.8,7.8)$ & $6.68 \mathrm{dd}(15.8,7.8)$ & & \\
\hline $9^{\prime}$ & $9.56 \mathrm{~d}(7.8)$ & $9.59 \mathrm{~d}(7.8)$ & & \\
\hline $1 " \mathrm{a}$ & $3.41 \mathrm{dq}(9.5,7.2)$ & $3.42 \mathrm{dq}(9.5,7.2)$ & $3.41 \mathrm{dq}(9.5,7.2)$ & $3.41 \mathrm{dq}(9.5,7.2)$ \\
\hline $1 " \mathrm{~b}$ & $3.36 \mathrm{dq}(9.5,7.2)$ & $3.36 \mathrm{dq}(9.5,7.2)$ & $3.36 \mathrm{dq}(9.5,7.2)$ & $3.35 \mathrm{dq}(9.5,7.2)$ \\
\hline $2^{\prime \prime}$ & $1.14 \mathrm{t}(7.2)$ & $1.08 \mathrm{t}(7.2)$ & $1.14 \mathrm{t}(7.2)$ & $1.06 \mathrm{t}(7.2)$ \\
\hline 3-OMe & $3.77 \mathrm{~s}$ & $3.82 \mathrm{~s}$ & $3.77 \mathrm{~s}$ & $3.81 \mathrm{~s}$ \\
\hline 3'-OMe & $3.80 \mathrm{~s}$ & $3.90 \mathrm{~s}$ & $3.81 \mathrm{~s}$ & $3.92 \mathrm{~s}$ \\
\hline
\end{tabular}

3.6 Hz, H-9a) and $3.85(1 \mathrm{H}, \mathrm{dd}, J=11.4,5.7 \mathrm{~Hz}, \mathrm{H}-9 \mathrm{~b})$ in 3 to $\delta 3.68$ $(1 \mathrm{H}, \mathrm{dd}, J=12.0,3.5 \mathrm{~Hz}, \mathrm{H}-9 \mathrm{a})$ and $3.53(1 \mathrm{H}, \mathrm{dd}, J=12.0,6.2 \mathrm{~Hz}, \mathrm{H}-$ $9 b$ ) in 4, along with the upfield shifts of C-7 (from 82.5 in $\mathbf{3}$ to 81.6 in 4) and C-8 (from 85.1 in 3 to 84.3 in 4), suggested that compound 4 should be the stereoisomer of 3 . The erythro-configuration was concluded by the $J_{7,8}$ value of $4.5 \mathrm{~Hz}$. Hence, compound 4 was elucidated as erythro-guaiacylethoxy glycerol- $\beta-0-4^{\prime}-$ guaiacyl aldehyde ether.

Compound 5 had a molecular formula of $\mathrm{C}_{28} \mathrm{H}_{28} \mathrm{O}_{9}$ with 15 degrees of unsaturation based on its $[\mathrm{M}+\mathrm{H}]^{+}$ion peak at $m / z$ 509.1778 (calcd. for 509.1806) in HRESIMS. The functional groups of hydroxyl $\left(3442 \mathrm{~cm}^{-1}\right)$, aromatic rings $(1516,1493$, and $\left.1452 \mathrm{~cm}^{-1}\right)$, and ether bonds $\left(1276,1136\right.$, and $1032 \mathrm{~cm}^{-1}$ ) were deduced from the IR spectrum. The ${ }^{1} \mathrm{H}$ NMR spectrum showed three methoxyls at $\delta 3.95,3.87$, and 3.84 (each $3 \mathrm{H}, \mathrm{s}$ ), one 1,3,4trisubstituted phenyl ring at $\delta 6.97(1 \mathrm{H}, \mathrm{d}, J=1.8 \mathrm{~Hz}, \mathrm{H}-2), 6.84$ $(1 \mathrm{H}, \mathrm{d}, J=8.1 \mathrm{~Hz}, \mathrm{H}-5)$, and $6.78(1 \mathrm{H}, \mathrm{dd}, J=8.1,1.8 \mathrm{~Hz}, \mathrm{H}-6)$, and two 1,3,4,5-substituted phenyl rings at $\delta 7.55,7.48,6.96$, and 6.94 (each $1 \mathrm{H}$ ). Three methoxy groups, eleven quaternary carbons, twelve methines, and two methylenes observed in the ${ }^{13} \mathrm{C}$ NMR (DEPT) spectrum indicated a sesquilignan skeleton. The proton resonances at $\delta_{\mathrm{H}} 7.55\left(\mathrm{H}-6^{\prime \prime}\right), 7.48\left(\mathrm{H}-2^{\prime \prime}\right), 6.96\left(\mathrm{H}-6^{\prime}\right), 6.94\left(\mathrm{H}-2^{\prime}\right)$, $5.73(\mathrm{H}-7)$, and $5.55\left(\mathrm{H}-7^{\prime}\right)$, together with the carbon resonances at $\delta_{\mathrm{C}} 154.1\left(\mathrm{C}-4^{\prime \prime}\right), 148.2\left(\mathrm{C}-4^{\prime}\right), 129.7\left(\mathrm{C}-5^{\prime}\right), 129.2$ (C-5"), 89.3 (C$7), 87.9\left(\mathrm{C}-7^{\prime}\right), 53.8(\mathrm{C}-8)$, and $53.0\left(\mathrm{C}-8^{\prime}\right)$, suggested the presence of two dihydrobenzofuran moieties. The correlations from $\mathrm{H}-2^{\prime}$ and $\mathrm{H}_{-} \mathbf{6}^{\prime}$ to $\mathrm{C}-\mathrm{7}^{\prime}$, and from $\mathrm{H}-\mathrm{7}^{\prime}$ to $\mathrm{C}-2^{\prime}$ and $\mathrm{C}-\mathrm{6}^{\prime}$ in $\mathrm{HMBC}$ ( Fig. 2) indicated the two dihydrobenzofuran moieties were linked by the $\mathrm{C}_{1}$ - $\mathrm{C}_{7}$, bond. The linkage of a guaiacyl moiety with C-7 was further confirmed by the correlations from $\mathrm{H}-2$ and $\mathrm{H}-6$ to $\mathrm{C}-7$, together with the correlations from $\mathrm{H}-7$ to $\mathrm{C}-2$ and $\mathrm{C}-6$ in the $\mathrm{HMBC}$ spectrum. Compared with the coupling constant $(6.9 \mathrm{~Hz})$ of $J_{7^{\prime}, 8^{\prime}}$ in rosalaevin A (8) [25], the trans-orientation of $\mathrm{H}-7$ and $\mathrm{H}-8$ was evident from the $J_{7,8}$ value of $6.9 \mathrm{~Hz}$, while the cis-configuration of $\mathrm{H}-7^{\prime}$ and $\mathrm{H}-8^{\prime}$ ' was verified by the $J_{7^{\prime}, 8^{\prime}}$ value of $4.7 \mathrm{~Hz}$. Thus, the structure of 5 was finally determined as trans-2guaiacyl-3-hydroxymethyl-5-(cis-3'-hydroxymethyl-5'-formyl7'-methoxybenzofuranyl)-7-methoxybenzofuran. 


\begin{tabular}{|c|c|c|c|}
\hline No. & 5 & 6 & 7 \\
\hline 2 & $6.97 \mathrm{~d}(1.8)$ & $6.97 \mathrm{~d}(1.8)$ & $6.94 \mathrm{~d}(1.8)$ \\
\hline 5 & $6.84 \mathrm{~d}(8.1)$ & $6.77 \mathrm{~d}(8.1)$ & $6.66 \mathrm{~d}(8.1)$ \\
\hline 6 & $6.78 \mathrm{dd}(8.1,1.8)$ & $6.73 \mathrm{dd}(8.1,1.8)$ & $6.75 \mathrm{dd}(8.1,1.8)$ \\
\hline 7 & $5.73 d(6.9)$ & $4.90 \mathrm{~d}(3.6)$ & $3.16 \mathrm{dd}(10.8,4.4)$ \\
\hline 8 & $3.68 \mathrm{ddd}(6.9,5.1,3.6)$ & $4.22 \mathrm{ddd}(5.6,3.8,3.6)$ & $4.45 \mathrm{ddd}(4.4,4.2,0.5)$ \\
\hline 9a & $3.91 \mathrm{dd}(9.4,3.6)$ & $3.89 \mathrm{dd}(12.2,5.6)$ & $4.42 \mathrm{dd}(9.4,4.2)$ \\
\hline $9 b$ & $3.89 \mathrm{dd}(9.4,5.1)$ & $3.56 \mathrm{dd}(12.2,3.8)$ & $3.99 \mathrm{dd}(9.4,0.5)$ \\
\hline $2^{\prime}$ & $6.94 d(1.3)$ & $6.65 d(1.9)$ & $6.82 \mathrm{~d}(1.8)$ \\
\hline $5^{\prime}$ & & & $6.71 \mathrm{~d}(8.1)$ \\
\hline $6^{\prime}$ & $6.96 \mathrm{~d}(1.3)$ & $6.65 \mathrm{~d}(1.9)$ & $6.70 \mathrm{dd}(8.1,1.8)$ \\
\hline $7^{\prime}$ & $5.55 d(4.7)$ & $4.83 \mathrm{~d}(6.9)$ & $5.13 d(10.8)$ \\
\hline $8^{\prime}$ & $3.52 \mathrm{ddd}(5.2,4.7,3.4)$ & $2.35 \mathrm{~m}$ & \\
\hline 9'a & $3.82 \mathrm{dd}(12.9,3.4)$ & $3.86 \mathrm{dd}(10.8,5.5)$ & \\
\hline $9^{\prime} b$ & $3.79 \mathrm{dd}(12.9,5.2)$ & $3.68 \mathrm{dd}(10.8,3.2)$ & \\
\hline $2^{\prime \prime}$ & $7.48 d(1.6)$ & 6.50 brs & \\
\hline 6" & $7.55 d(1.6)$ & 6.50 brs & \\
\hline 7"а & $9.81 \mathrm{~s}$ & $2.92 \mathrm{dd}(13.4,5.9)$ & \\
\hline 7"b & & $2.50 \mathrm{dd}(13.4,10.4)$ & \\
\hline $8^{\prime \prime}$ & & $2.71 \mathrm{~m}$ & \\
\hline 9"а & & $4.01 \mathrm{dd}(9.6,2.6)$ & \\
\hline $9 " b$ & & $3.76 \mathrm{dd}(9.6,6.4)$ & \\
\hline 3-OMe & $3.87 \mathrm{~s}$ & $3.82 \mathrm{~s}$ & $3.82 \mathrm{~s}$ \\
\hline 3'-OMe & $3.95 \mathrm{~s}$ & $3.81 \mathrm{~s}$ & $3.75 \mathrm{~s}$ \\
\hline 3"-OMe & $3.84 \mathrm{~s}$ & $3.81 \mathrm{~s}$ & \\
\hline 5'-OMe & & $3.81 \mathrm{~s}$ & \\
\hline 5"-OMe & & $3.81 \mathrm{~s}$ & \\
\hline
\end{tabular}

Table $2{ }^{1} \mathrm{H}-\mathrm{NMR}(600 \mathrm{MHz})$ data for compounds 5-7 in $\mathrm{CD}_{3} \mathrm{OD}$ ( $\delta$ in ppm, J in $\mathrm{Hz}$ ).

Table $3{ }^{13} \mathrm{C}-\mathrm{NMR}(150 \mathrm{MHz})$ data for compounds $\mathbf{1 - 7}$ in $\mathrm{CD}_{3} \mathrm{OD}$ ( $\delta_{\mathrm{C}}$ values).

\begin{tabular}{|c|c|c|c|c|c|c|c|}
\hline No. & 1 & 2 & 3 & 4 & 5 & 6 & 7 \\
\hline 1 & $131.4 \mathrm{~s}$ & $131.3 \mathrm{~s}$ & $131.6 \mathrm{~s}$ & $131.6 \mathrm{~s}$ & $134.3 \mathrm{~s}$ & $133.8 \mathrm{~s}$ & $133.8 \mathrm{~s}$ \\
\hline 2 & $112.0 \mathrm{~d}$ & $112.5 \mathrm{~d}$ & $111.9 \mathrm{~d}$ & $112.4 \mathrm{~d}$ & $110.5 d$ & $111.3 d$ & $114.7 d$ \\
\hline 3 & $149.1 \mathrm{~s}$ & $148.8 \mathrm{~s}$ & $149.1 \mathrm{~s}$ & $148.8 \mathrm{~s}$ & $144.2 \mathrm{~s}$ & $148.7 \mathrm{~s}$ & $148.9 \mathrm{~s}$ \\
\hline 4 & $147.5 \mathrm{~s}$ & $147.4 \mathrm{~s}$ & $147.6 \mathrm{~s}$ & $147.4 \mathrm{~s}$ & $146.2 \mathrm{~s}$ & $146.8 \mathrm{~s}$ & $146.7 \mathrm{~s}$ \\
\hline 5 & $116.0 \mathrm{~d}$ & $115.6 \mathrm{~d}$ & $116.0 \mathrm{~d}$ & $115.6 \mathrm{~d}$ & $114.4 d$ & $115.7 d$ & $115.9 \mathrm{~d}$ \\
\hline 6 & $121.4 \mathrm{~d}$ & $122.0 \mathrm{~d}$ & $121.4 d$ & $122.0 \mathrm{~d}$ & $114.8 \mathrm{~d}$ & $120.6 \mathrm{~d}$ & $123.9 \mathrm{~d}$ \\
\hline 7 & $82.5 \mathrm{~d}$ & $81.7 \mathrm{~d}$ & $82.5 \mathrm{~d}$ & $81.6 \mathrm{~d}$ & $89.3 \mathrm{~d}$ & $74.0 \mathrm{~d}$ & $60.2 d$ \\
\hline 8 & $85.3 d$ & $84.6 \mathrm{~d}$ & $85.1 \mathrm{~d}$ & $84.3 \mathrm{~d}$ & $53.8 \mathrm{~d}$ & $87.4 \mathrm{~d}$ & $76.0 \mathrm{~d}$ \\
\hline 9 & $62.4 \mathrm{t}$ & $62.5 \mathrm{t}$ & $62.3 \mathrm{t}$ & $62.5 t$ & $63.3 \mathrm{t}$ & $61.6 \mathrm{t}$ & $77.1 \mathrm{t}$ \\
\hline $1^{\prime}$ & $129.1 \mathrm{~s}$ & $129.1 \mathrm{~s}$ & $131.3 \mathrm{~s}$ & $131.1 \mathrm{~s}$ & $133.0 \mathrm{~s}$ & $141.0 \mathrm{~s}$ & $128.6 \mathrm{~s}$ \\
\hline $2^{\prime}$ & $112.7 d$ & $112.7 d$ & $111.5 \mathrm{~d}$ & $111.4 \mathrm{~d}$ & $109.1 \mathrm{~d}$ & $104.0 \mathrm{~d}$ & $111.0 \mathrm{~d}$ \\
\hline $3^{\prime}$ & $151.7 \mathrm{~s}$ & $151.7 \mathrm{~s}$ & $151.7 \mathrm{~s}$ & $151.7 \mathrm{~s}$ & $144.9 \mathrm{~s}$ & $154.4 \mathrm{~s}$ & $148.8 \mathrm{~s}$ \\
\hline $4^{\prime}$ & $153.6 \mathrm{~s}$ & $152.8 \mathrm{~s}$ & $156.3 \mathrm{~s}$ & $155.5 \mathrm{~s}$ & $148.2 \mathrm{~s}$ & $134.8 \mathrm{~s}$ & $147.3 \mathrm{~s}$ \\
\hline $5^{\prime}$ & $117.2 \mathrm{~d}$ & $117.1 \mathrm{~d}$ & $116.0 \mathrm{~d}$ & $115.8 \mathrm{~d}$ & $129.7 \mathrm{~s}$ & $154.4 \mathrm{~s}$ & $116.0 \mathrm{~d}$ \\
\hline $6^{\prime}$ & $124.5 d$ & $124.3 d$ & $127.2 \mathrm{~d}$ & $127.0 \mathrm{~d}$ & $118.3 \mathrm{~d}$ & $104.0 \mathrm{~d}$ & $120.5 d$ \\
\hline $7^{\prime}$ & $155.6 \mathrm{~d}$ & $155.5 d$ & $192.9 \mathrm{~d}$ & $192.9 \mathrm{~d}$ & $87.9 \mathrm{~d}$ & $84.0 \mathrm{~d}$ & $84.8 \mathrm{~d}$ \\
\hline $8^{\prime}$ & $127.6 \mathrm{~d}$ & $127.6 \mathrm{~d}$ & & & $53.0 \mathrm{~d}$ & $54.2 \mathrm{~d}$ & \\
\hline $9^{\prime}$ & $196.1 \mathrm{~d}$ & $196.1 \mathrm{~d}$ & & & $63.1 \mathrm{t}$ & $60.6 \mathrm{t}$ & \\
\hline $1^{\prime \prime}$ & $65.6 \mathrm{t}$ & $65.3 \mathrm{t}$ & $65.6 \mathrm{t}$ & $65.3 t$ & $131.4 \mathrm{~s}$ & $132.8 \mathrm{~s}$ & \\
\hline $2^{\prime \prime}$ & $15.6 \mathrm{q}$ & $15.6 \mathrm{q}$ & $15.5 q$ & $15.6 \mathrm{q}$ & $112.5 \mathrm{~d}$ & $106.8 d$ & \\
\hline $3^{\prime \prime}$ & & & & & $147.7 \mathrm{~s}$ & $149.3 \mathrm{~s}$ & \\
\hline $4^{\prime \prime}$ & & & & & $154.1 \mathrm{~s}$ & $135.8 \mathrm{~s}$ & \\
\hline $5^{\prime \prime}$ & & & & & $129.2 \mathrm{~s}$ & $149.3 \mathrm{~s}$ & \\
\hline 6" & & & & & $120.9 d$ & $106.8 d$ & \\
\hline $7^{\prime \prime}$ & & & & & $191.3 d$ & $34.1 \mathrm{t}$ & \\
\hline $8^{\prime \prime}$ & & & & & & $43.8 \mathrm{~d}$ & \\
\hline $9^{\prime \prime}$ & & & & & & $73.7 t$ & \\
\hline 3-OMe & $56.3 q$ & $56.3 q$ & $56.3 q$ & $56.3 \mathrm{q}$ & $55.3 \mathrm{q}$ & $56.3 q$ & $56.5 \mathrm{q}$ \\
\hline 3'-OMe & $56.6 q$ & $56.6 \mathrm{q}$ & $56.5 q$ & $56.4 \mathrm{q}$ & $55.4 \mathrm{q}$ & $56.7 q$ & $56.3 q$ \\
\hline 5'-OMe & & & & & & $56.7 q$ & \\
\hline 3"-OMe & & & & & $55.0 \mathrm{q}$ & $56.6 q$ & \\
\hline $5^{\prime \prime}$-OMe & & & & & & $56.6 q$ & \\
\hline
\end{tabular}



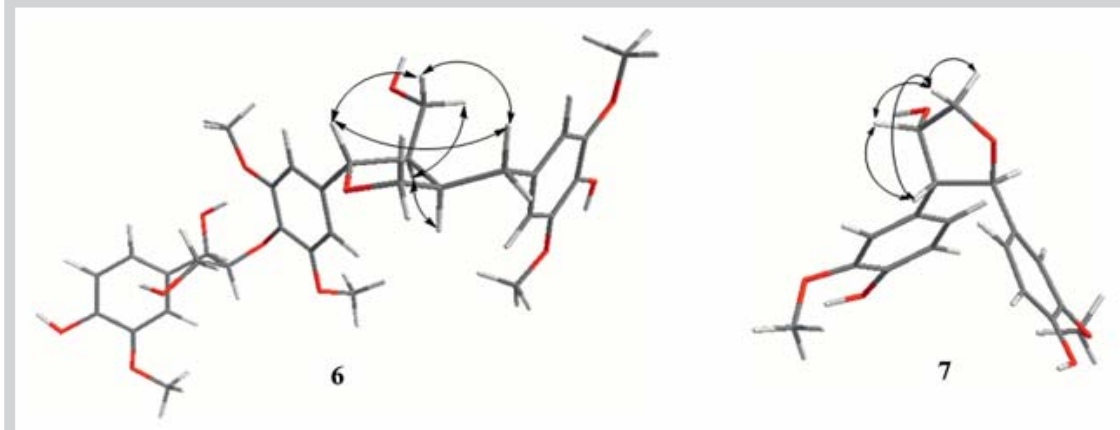

Fig. 3 The key correlations in ROESY experiments of compounds 6-7. (Color figure available online only.)

Compound 6 had a molecular formula of $\mathrm{C}_{32} \mathrm{H}_{40} \mathrm{O}_{12}$ with 13 degrees of unsaturation determined by its quasi-molecular ion peak at $m / z 639.2400[\mathrm{M}+\mathrm{Na}]^{+}$(calcd. for 639.2412) in the positive HRESIMS. The sesquilignan structure was evident from the existence of one 1,3,4-trisubstituted aromatic ring at $\delta 6.97(1 \mathrm{H}, \mathrm{d}$, $J=1.8 \mathrm{~Hz}, \mathrm{H}-2), 6.77(1 \mathrm{H}, \mathrm{d}, J=8.1 \mathrm{~Hz}, \mathrm{H}-5)$, and $6.73(1 \mathrm{H}, \mathrm{dd}$, $J=8.1,1.8 \mathrm{~Hz}, \mathrm{H}-6)$, and two $1,3,4,5$-substituted phenyl rings $(\delta$ 6.65 and 6.50 , each $2 \mathrm{H}$ ) in the ${ }^{1} \mathrm{H}$ NMR spectrum (Table 2). Comparing the ${ }^{1} \mathrm{H}$ and ${ }^{13} \mathrm{C}$ NMR (DEPT) data with those of rosalaevins A (8), the presence of an additional methoxyl at C-5" in 6 was confirmed by the downfield shift of $C-5$ " from $\delta_{C} 114.4$ in 8 to 149.3 in 6 , and the correlation of $\delta_{\mathrm{H}} 3.81$ to $\delta_{\mathrm{C}} 149.3$ in the HMBC spectrum ( Fig. 2). The $J_{7,8}(3.6 \mathrm{~Hz})$ and $J_{7^{\prime}, 8^{\prime}}(6.9 \mathrm{~Hz})$ values indicated the 7,8-erythro configuration and $77^{\prime}, 8^{\prime}$-trans orentation [25]. Furthermore, the absence of a ROESY correlation of $\mathrm{H}-7^{\prime} / \mathrm{H}-$ $8^{\prime \prime}$ together with the correlations of $\mathrm{H}-7^{\prime} / \mathrm{H}-8^{\prime} / \mathrm{H}-9^{\prime}, \mathrm{H}-7^{\prime} / \mathrm{H}-7^{\prime \prime}(\delta$ 2.50 ), $\mathrm{H}-8^{\prime} / \mathrm{H}-8^{\prime \prime}$ and $\mathrm{H}-7^{\prime \prime} / \mathrm{H}-9^{\prime}$ ( $\delta$ 3.86) (๑ Fig. 3) indicated the trans-orentation of $\mathrm{H}-7^{\prime}$ and $\mathrm{H}-8^{\prime \prime}$. Hence, the structure of 6 was deduced as erythro-guaiacylglycerol- $\beta-0-4^{\prime}-(+)-5,5^{\prime}$-dimethoxylariciresinol ether.

Compound 7 was obtained as pale yellow oil, and had a molecular formula of $\mathrm{C}_{18} \mathrm{H}_{20} \mathrm{O}_{6}$ by the negative HRESIMS at $m / z 331.1157$ $[\mathrm{M}-\mathrm{H}]^{-}$, requiring nine degrees of unsaturation. The hydroxy (3494 and $3444 \mathrm{~cm}^{-1}$ ), aromatic $\left(1609,1517\right.$ and $1456 \mathrm{~cm}^{-1}$ ), and ether bond $\left(1274,1233,1124\right.$, and $\left.1034 \mathrm{~cm}^{-1}\right)$ groups were revealed in the IR spectrum. In the ${ }^{1} \mathrm{H}$ NMR spectrum, signals of two 1,3,4-trisubstituted aromatic groups at $\delta 6.94(1 \mathrm{H}, \mathrm{d}$, $J=1.8 \mathrm{~Hz}, \mathrm{H}-2), 6.66(1 \mathrm{H}, \mathrm{d}, J=8.1 \mathrm{~Hz}, \mathrm{H}-5)$ and $6.75(1 \mathrm{H}, \mathrm{dd}$, $J=8.1,1.8 \mathrm{~Hz}, \mathrm{H}-6), \delta 6.82\left(1 \mathrm{H}, \mathrm{d}, J=1.8 \mathrm{~Hz}, \mathrm{H}-2^{\prime}\right), 6.71(1 \mathrm{H}, \mathrm{d}$, $\left.J=8.1 \mathrm{~Hz}, \mathrm{H}-5^{\prime}\right)$ and $6.70\left(1 \mathrm{H}, \mathrm{dd}, J=8.1,1.8 \mathrm{~Hz}, \mathrm{H}-6^{\prime}\right)$, together with signals of a substituted epoxybutyl unit, were unambiguously designated by ${ }^{1} \mathrm{H}-{ }^{1} \mathrm{H}$ COSY and $\mathrm{HSQC}$ experiments ( Fig. 2). The correlations from $\mathrm{H}-2$ and $\mathrm{H}-6$ to $\mathrm{C}-7$, from $\mathrm{H}-7$ to C-2 and C-6, from $\mathrm{H}-2$ ' and $\mathrm{H}-6$ ' to $\mathrm{C}-\mathbf{7}^{\prime}$, and from $\mathrm{H}-\mathbf{7}^{\prime}$ to $\mathrm{C}-2^{\prime}$ and C-6' in the HMBC experiment suggested that two 4-hydroxy-3methoxybenzyl units were located at C-7 and C-7', respectively. Therefore, the planar structure of $\mathbf{7}$ was established as norlignan from the ${ }^{1} \mathrm{H}$ and ${ }^{13} \mathrm{C}$ NMR data (- Tables 2 and 3). The 7,8-cis and $7,7^{\prime}$-trans orentation were indicated by the $J_{7,8}(4.4 \mathrm{~Hz})$ and $J_{7,7^{\prime}}$ $(10.8 \mathrm{~Hz})$ values, which were confirmed by the ROESY experiment ( Fig. 3). Finally, compound 7 was elucidated as $\left(2 R^{*}, 3 R^{*}, 4 S^{*}\right)-2,3$-diguaiacyl-4-hydroxyl tetrahydrofuran.

The known lignans were identified as rosalaevins $A(8)$ [25], ficusesquilignans A (9) [26], buddlenol E (10) [27], 5'-demethoxybuddlenol E (11) [28], leptolepisol D (12) [24], lyoniside (13) [29], picrasmalignan A (14) [30], threo-guaiacylglycerol- $\beta$-coniferyl aldehyde ether (15) [19], erythro-guaiacylglycerol- $\beta$-coniferyl aldehyde ether (16) [19], threo-guaiacylglycerol- $\beta$-coniferyl ether (17) [31], erythro-guaiacylglycerol- $\beta$-coniferyl ether (18) [31], erythro-dihydroxydehydrodiconifery alcohol (19) [20], vladinol D (20) [32], (-)-secoisolariciresinol (21) [33], ficusal (22) [26], (2S)-3,3-diguaiacyl-1,2-propanediol (23) [34], and (+)-pinoresinol (24) [19] by comparing their spectroscopic data with the literature.

Seven new compounds (1-7) and the abundant known (+)-pinoresinol (24) were evaluated for agonistic activity on human melatonin receptor $\mathrm{MT}_{1}$ on HEK293 cell lines in vitro. As shown in - Table 4, (+)-pinoresinol (24), the major lignan, exhibited the strongest agonistic effect among the tested compounds with an agonistic rate of $57.77 \%$ at the concentration of $1.02 \mathrm{mM}$. Compounds 7 and 2 possessed moderate agonistic activities on $\mathrm{MT}_{1}$ with agonistic rates of $37.55 \%$ and $21.16 \%$ at about $1.00 \mathrm{mM}$, respectively. Compounds $\mathbf{1}$ and $\mathbf{5}$ showed weak agonistic activities on $\mathrm{MT}_{1}$, while no obvious effects for compounds 3, 4, and $\mathbf{6}$ were detected at the tested concentration.

Pharmacological studies demonstrated that serotonin (5-hydroxytryptamine, 5-HT) receptors, especially the subtypes of 5$\mathrm{HT}_{1 \mathrm{~A}}$ and $5-\mathrm{HT}_{2} \mathrm{C}$, were closely involved in the pathogenesis and treatment of psychiatric problems such as depression and anxiety disorders $[35,36]$. Consequently, these compounds were further assayed for the agitating activities on $5-\mathrm{HT}_{1 \mathrm{~A}}$ and $5-\mathrm{HT}_{2 \mathrm{C}}$ receptors on HEK293 cell lines in vitro. However, no meaningful agonistic activities were observed at the concentration of about $1 \mathrm{mM}$ (॰ Table 4).

Different from the previous research, this investigation was focused on the lignans and resulted in seven new together with seventeen known ones. A bioassay on HEK293 cell lines in vitro revealed that (+)-pinoresinol (24) exhibited a moderate activity against $\mathrm{MT}_{1}$ mediation. This study may provide another view for understanding the active components of "Chuan-Lian-Zi".

\section{Materials and Methods \\ $\nabla$}

\section{General}

Melting points (m.p.) were measured by an SGW ${ }^{\circledR} \mathrm{X}-4 \mathrm{~B}$ melting point apparatus. UV spectra were recorded on a UV-2401A spectrophotometer with methanol $(\mathrm{MeOH})$ as the solvent. Optical rotations were obtained on a Jasco model 1020 polarimeter in $\mathrm{MeOH}$ solution. IR spectra were collected on a Bio-Rad FTS-135 spectrometer with $\mathrm{KBr}$ pellets. HRESIMS data were acquired on a liquid chromatography-mass spectrometry-ion trap-time-offlight (LCMS-IT-TOF). 1D and 2D NMR experiments were carried out using Advance III-600 NMR spectrometers with tetramethylsilane (TMS) as an internal standard. Semipreparative HPLC was performed on a Newstyle ${ }^{\mathrm{TM}}$ (pump: NP-7000 serials, detector: 


\begin{tabular}{|c|c|c|c|c|c|}
\hline \multirow[t]{2}{*}{ Compounds } & \multirow[t]{2}{*}{ Test concentration (mM) } & \multicolumn{3}{|c|}{ Agonistic rate ${ }^{\mathrm{d}}(\%)$} & \multirow{10}{*}{$\begin{array}{l}\text { Table } 4 \text { Agonistic activities of } \\
\text { compounds } 1-7 \text { and } 24 \text { on } \mathrm{MT}_{1}^{\mathrm{a}} \text {, } \\
5-\mathrm{HT}_{1 \mathrm{~A}^{\mathrm{b}}} \text {, and } 5-\mathrm{HT}_{2} \mathrm{C}^{\mathrm{c}} \text { receptors. }\end{array}$} \\
\hline & & $\mathrm{MT}_{1}$ & $5-\mathrm{HT}_{1 \mathrm{~A}}$ & $5-\mathrm{HT}_{2 \mathrm{C}}$ & \\
\hline 1 & 0.91 & 4.28 & 0.64 & 6.94 & \\
\hline 2 & 0.99 & 21.16 & 5.07 & 9.80 & \\
\hline 3 & 0.97 & NDe & ND & 5.08 & \\
\hline 4 & 0.95 & ND & 3.49 & 11.39 & \\
\hline 5 & 1.05 & 8.04 & ND & 10.28 & \\
\hline 6 & 0.92 & ND & 7.73 & 5.25 & \\
\hline 7 & 0.90 & 37.55 & ND & 7.89 & \\
\hline 24 & 1.02 & 57.77 & 14.88 & 7.40 & \\
\hline
\end{tabular}

${ }^{a}$ The positive control was melatonin $\left(\mathrm{EC}_{50} 0.54 \mathrm{nM}\right)$; ${ }^{\mathrm{b}}$ the positive control was 5 -hydroxytryptamine $\left(\mathrm{EC}_{50} 43.28 \mathrm{nM}\right)$; ${ }^{\mathrm{c}}$ the positive control was 5-hydroxytryptamine ( $\mathrm{EC}_{50} 0.94 \mathrm{nM}$ ); ${ }^{\mathrm{d}}$ the agonistic rate was the percentage versus the control (normalized to $100 \%$ ) and was the average of two independent tests; ${ }^{\text {e }}$ no agonistic activity was detected

NU-3000 serials) with a reversed-phase (RP) $\mathrm{C}_{18}$ column $(9.4 \times$ $250 \mathrm{~mm}, 5 \mu \mathrm{m})$. Silica gel (200-300 mesh), MCI gel CHP-20P, and Sephadex LH-20 were used for column chromatography (CC). Thin-layer chromatography (TLC) was conducted on silica gel $\mathrm{GF}_{254}$ plates and the spots were visualized under UV light or by spraying with $10 \% \mathrm{H}_{2} \mathrm{SO}_{4}$ in $95 \%$ ethanol (EtOH) followed by heating. Melatonin (purity $>99 \%$ ) and serotonin hydrochloride (purity $>99 \%$ ) were purchased from Alfa Aesar as positive controls.

\section{Plant material}

The fruit of M. toosendan Sieb. et Zucc. was purchased from Jvhuacun traditional Chinese medicine market, Kunming, Yunnan Province of China, in July 2012, and identified by Prof. Dr. Li-Gong Lei, Kunming Institute of Botany (KIB), Chinese Academy of Sciences (CAS). A voucher specimen (No. 2012-07-18) was deposited in the Laboratory of Antivirus and Natural Medicinal Chemistry, KIB, CAS.

\section{Extraction and isolation}

The air-dried and powdered fruit of $M$. toosendan (6 kg) was extracted with $90 \%$ EtOH at room temperature three times, each for $24 \mathrm{~h}$. All the extracts were combined and condensed in vacuo and partitioned between EtOAc and $\mathrm{H}_{2} \mathrm{O}$ to afford EtOAc part $125 \mathrm{~g}$. The EtOAc part was subjected to silica gel column chromatograph (SiCC, $900 \mathrm{~g}, 14 \times 65 \mathrm{~cm}$ ) eluted with $\mathrm{H}_{2} \mathrm{O}-\mathrm{MeOH}_{-} \mathrm{CHCl}_{3}(0: 0$ : $100,0: 5: 95,0: 10: 90,2: 20: 80, \mathrm{v} / \mathrm{v} / \mathrm{v}$, each $15 \mathrm{~L})$ to afford Frs. $1-5$ based on the TLC characteristics. According to our in vitro bioassay (Table 1S, Supporting Information), Fr. 3 (71.5 g) was further separated by SiCC to obtain Frs. 3-1 3-6. Fr. 3-1 $(11.1 \mathrm{~g})$ was fractionated by MCI CHP-20P gel CC to get Frs. 3-1$1 \sim 3-1-5$. Fr. 3-1-3 was subjected to repeated SiCC and further purified by semipreparative HPLC (Zorbax- $C_{18}, 5.0 \mu \mathrm{m}, 9.4 \times$ $250 \mathrm{~mm}$, UV detection at $\lambda_{\max }=210,254 \mathrm{~nm}$ ) using $\mathrm{MeOH}-\mathrm{H}_{2} \mathrm{O}$ (18:82, flow rate $3 \mathrm{~mL} / \mathrm{min}$ ) to obtain compound 7 (6 mg, $t_{R}=26$ min, purity $>98 \%$ detected by HPLC). Fr. $3-2$ ( $\left.4.5 \mathrm{~g}\right)$ was partitioned by repeated SiCC to obtain Frs. 3-2-2-1 3-2-2-5. Fr. 3-2-2-1 was purified by semipreparative HPLC with $\mathrm{MeOH}-\mathrm{H}_{2} \mathrm{O}(65: 35$, flow rate $2.5 \mathrm{~mL} / \mathrm{min})$ to afford compounds $3\left(5 \mathrm{mg}, t_{\mathrm{R}}=36 \mathrm{~min}\right.$, purity $\left.>97 \%\right)$ and $4\left(5 \mathrm{mg}, t_{\mathrm{R}}=38 \mathrm{~min}\right.$, purity $>96 \%$ ). Fr. 3-2-2-2 was purified by Sephadex LH-20 CC to get compound 24 (910 mg, purity $>95 \%$ ). Fr. 3-2-2-3 was purified by semipreparative HPLC with $\mathrm{MeOH}-\mathrm{H}_{2} \mathrm{O}$ (60:40, flow rate $3 \mathrm{~mL} / \mathrm{min}$ ) to obtain compounds $1\left(7 \mathrm{mg}, t_{\mathrm{R}}=31 \mathrm{~min}\right.$, purity $>96 \%$ ) and 2 ( $8 \mathrm{mg}, t_{\mathrm{R}}=32.5 \mathrm{~min}$, purity $\left.>96 \%\right)$. Fr. $3-3(10.2 \mathrm{~g})$ was subjected to MCI CHP-20P gel CC, SiCC, and Sephadex LH-20
CC, respectively, and finally purified by semipreparative HPLC to yield known compounds 17 (12 mg), 18 (10 mg), and 22 (30 mg). Fr. 3-4 (3.9 g) was successively partitioned by MCI CHP-20P gel CC, SiCC, and semipreparative HPLC to obtain known compounds 15 ( $21 \mathrm{mg}$ ), 16 (30 mg), and 23 (27 mg). Fr. 3-5 (2.7 g) was repeatedly isolated to yield compounds 9 (30 mg), 10 (11 mg), 13 (10 mg), and Fr. 3-5-2-5-3 (51 mg), which was further separated by semipreparative HPLC eluted with $\mathrm{MeCN}-\mathrm{H}_{2} \mathrm{O}$ (28:72, flow rate $3 \mathrm{~mL} / \mathrm{min}$ ) to yield compounds $5\left(7 \mathrm{mg}, t_{\mathrm{R}}=19 \mathrm{~min}\right.$, purity $>97 \%$ ) and 14 (9 mg). Fr. 3-6 (7.8 g) was partitioned by repeated CC and finally purified by semipreparative HPLC eluted with MeCN- $\mathrm{H}_{2} \mathrm{O}(28: 72$, flow rate $3 \mathrm{~mL} / \mathrm{min})$ to yield compounds 6 ( $4 \mathrm{mg}, t_{\mathrm{R}}=17.5 \mathrm{~min}$, purity $>97 \%$ ) and 8 (9 mg). Fr. $4(14 \mathrm{~g})$ was repeatedly isolated to afford compound $19(13 \mathrm{mg})$ and Fr. 5 $(7.8 \mathrm{~g})$ was partitioned to obtain compounds 11 (5 mg), 12 (13 $\mathrm{mg}$ ), and 21 (3 $\mathrm{mg}$ ), respectively (the detailed isolation procedure is provided in Supporting Information). The purities of all known compounds were $>95 \%$ as determined by HPLC.

threo-Guaiacylethoxyglycerol- $\beta$-0-4'-coniferyl aldehyde ether (1): pale yellow amorphous powder, m.p. $59-61{ }^{\circ} \mathrm{C} ;[\alpha]_{\mathrm{D}}^{20}:-3.93(c$ 0.10, $\mathrm{MeOH}) ; \mathrm{UV}(\mathrm{MeOH}) \lambda_{\max }(\log \varepsilon): 337$ (4.21) nm; IR (KBr) $v_{\max } 3428,1666,1597,1511,1460,1273,1130,1033,867$, $816 \mathrm{~cm}^{-1} ;{ }^{1} \mathrm{H}(600 \mathrm{MHz})$ and ${ }^{13} \mathrm{C}$ NMR $(150 \mathrm{MHz})$ data see $\odot \mathrm{Ta}-$ bles 1 and 3; (+)HRESIMS m/z 425.1585 [M + Na ${ }^{+}$(calcd. for $\mathrm{C}_{22} \mathrm{H}_{26} \mathrm{O}_{7} \mathrm{Na}, 425.1571$ ).

erythro-Guaiacylethoxyglycerol- $\beta-0-4^{\prime}$-coniferyl aldehyde ether (2): pale yellow amorphous powder, m.p. $43-45^{\circ} \mathrm{C}$; $[\alpha]_{\mathrm{D}}^{20}:-6.13$ (c 0.10, MeOH); UV (MeOH) $\lambda_{\max }(\log \varepsilon): 337$ (3.89) nm; IR (KBr) $v_{\max } 3441,1661,1597,1511,1454,1272,1130,1032,875$, $819 \mathrm{~cm}^{-1} ;{ }^{1} \mathrm{H}(600 \mathrm{MHz})$ and ${ }^{13} \mathrm{C}$ NMR $(150 \mathrm{MHz})$ data see $\bullet$ Tables 1 and 3; (+)HRESIMS m/z 425.1589 [M + Na $]^{+}$(calcd. for $\mathrm{C}_{22} \mathrm{H}_{26} \mathrm{O}_{7} \mathrm{Na}, 425.1571$ ).

threo-Guaiacylethoxyglycerol- $\beta-0-4$ '-guaiacyl aldehyde ether (3): pale yellow oil; $[\alpha]_{\mathrm{D}}^{20}:-4.52($ c $0.09, \mathrm{MeOH}) ; \mathrm{UV}(\mathrm{MeOH}) \lambda_{\max }$ $(\log \varepsilon)$ : 309 (3.50), 279 (3.67), 228 (3.85) nm; IR (KBr) $v_{\max } 3449$, $1673,1594,1510,1463,1273,1130,1033,867,814 \mathrm{~cm}^{-1} ;{ }^{1} \mathrm{H}$ $(600 \mathrm{MHz})$ and ${ }^{13} \mathrm{C}$ NMR $(150 \mathrm{MHz})$ data see Tables 1 and 3; $(+)$ HRESIMS $m / z$ 399.1435 $[\mathrm{M}+\mathrm{Na}]^{+}$(calcd. for $\mathrm{C}_{20} \mathrm{H}_{24} \mathrm{O}_{7} \mathrm{Na}$, 399.1414).

erythro-Guaiacylethoxyglycerol- $\beta-0-4$ '-guaiacyl aldehyde ether (4): pale yellow oil; $[\alpha]_{D}^{20}$ : -9.07 ( $\left.0.09, \mathrm{MeOH}\right)$; UV (MeOH) $\lambda_{\max }$ $(\log \varepsilon)$ : 309 (3.57), 279 (3.71), 228 (3.88) nm; IR (KBr) $v_{\max } 3450$, $1677,1596,1508,1466,1271,1136,1031,868,815 \mathrm{~cm}^{-1} ;{ }^{1} \mathrm{H}$ $(600 \mathrm{MHz})$ and ${ }^{13} \mathrm{C}$ NMR $(150 \mathrm{MHz})$ data see Tables 1 and 3; (+)HRESIMS $m / z$ 399.1405 $[\mathrm{M}+\mathrm{Na}]^{+}$(calcd. for $\mathrm{C}_{20} \mathrm{H}_{24} \mathrm{O}_{7} \mathrm{Na}$, 399.1414). 
trans-2-Guaiacyl-3-hydroxymethyl-5-(cis-3'-hydroxymethyl-5'formyl-7'-methoxybenzofuranyl)-7-methoxybenzofuran (5): pale yellow amorphous powder, m.p. 67-69 ${ }^{\circ} \mathrm{C} ;[\alpha]_{\mathrm{D}}^{20}$ : -10.38 (c 0.07, $\mathrm{MeOH}) ; \mathrm{UV}(\mathrm{MeOH}) \lambda_{\max }(\log \varepsilon): 378$ (2.36), 288 (4.10), 235 (4.33) nm; IR (KBr) $v_{\max } 3442,1631,1516,1493,1452,1276$, 1136, $1032 \mathrm{~cm}^{-1} ;{ }^{1} \mathrm{H}(600 \mathrm{MHz})$ and ${ }^{13} \mathrm{C}$ NMR (150 MHz) data see - Tables 2 and 3; (+)HRESIMS m/z 509.1778 [M + H] ${ }^{+}$(calcd. for $\left.\mathrm{C}_{28} \mathrm{H}_{29} \mathrm{O}_{9}, 509.1806\right)$.

erythro-Guaiacylglycerol- $\beta-0-4^{\prime}-(+)-5,5^{\prime}$-dimethoxylariciresinol ether (6): pale yellow amorphous powder, m.p. $92-94^{\circ} \mathrm{C} ;[\alpha]_{\mathrm{D}}^{20}$ : - 9.00 (с 0.20, MeOH); UV (MeOH) $\lambda_{\max }(\log \varepsilon): 378$ (2.74), 279 (3.73) nm; IR (KBr) $v_{\max } 3441,3433,1620,1517,1462,1274$, 1121, 1035, 877, $857 \mathrm{~cm}^{-1} ;{ }^{1} \mathrm{H}(600 \mathrm{MHz})$ and ${ }^{13} \mathrm{C}$ NMR $(150 \mathrm{MHz}$ ) data see Tables 2 and 3; (+)HRESIMS m/z 639.2400 $[\mathrm{M}+\mathrm{Na}]^{+}$(calcd. for $\mathrm{C}_{32} \mathrm{H}_{40} \mathrm{O}_{12} \mathrm{Na}, 639.2412$ ).

$\left(2 R^{*}, 3 R^{*}, 4 S^{*}\right)$-2,3-Diguaiacyl-4-hydroxyl tetrahydrofuran (7): pale yellow oil; $[\alpha]_{\mathrm{D}}^{20}$ : -5.25 ( $\left.0.08, \mathrm{MeOH}\right)$; $\mathrm{UV}(\mathrm{MeOH}) \lambda_{\max }(\log \varepsilon)$ : 281 (3.88), 228 (4.26) nm; IR (KBr) $v_{\max } 3494,3444,1609,1517$, $1456,1274,1233,1124,1034,874,817 \mathrm{~cm}^{-1} ;{ }^{1} \mathrm{H}(600 \mathrm{MHz})$ and ${ }^{13} \mathrm{C}$ NMR $(150 \mathrm{MHz})$ data see Tables 2 and 3; (-)HRESIMS m/z $331.1157[\mathrm{M}-\mathrm{H}]^{-}$(calcd. for $\mathrm{C}_{18} \mathrm{H}_{19} \mathrm{O}_{6}, 331.1187$ ).

\section{Agonistic activity assay}

The agonistic rates of the test compounds were performed according to our previous report [37].

\section{Supporting information}

1D and 2D NMR spectra as well as HRESIMS spectra of the seven new compounds, detailed extraction and isolation, and the procedure of the bioassay are available as Supporting Information.

\section{Acknowledgements}

$\nabla$

This work was supported by the National Science Foundation of China for Distinguished Young Scholars (No. 81 025023), the National Natural Science Foundation of China (No. 81 202436), and the Youth Innovation Promotion Association, CAS. The authors sincerely thank the staff of the analytical group of the State Key Laboratory of Phytochemistry and Plant Resources in West China, Kunming Institute of Botany, CAS.

\section{Conflict of Interest}

$\nabla$

The authors declare no conflict of interest.

\section{References}

1 Tada K, Takido M, Kitanaka S. Limonoids from fruit of Melia toosendan and their cytotoxic activity. Phytochemistry 1999; 51: 787-791

2 Xie F, Zhang M, Zhang CF, Wang ZT, Yu BY, Kou JP. Anti-inflammatory and analgesic activities of ethanolic extract and two limonoids from Melia toosendan fruit. J Ethnopharmacol 2008; 117: 463-466

3 Zhang Y, Tang CP, Ke CQ Li XQ Xie H, Ye Y. Limonoids from the fruits of Melia toosendan. Phytochemistry 2012; 73: 106-113

4 State Pharmacopoeia Committee. Chinese Pharmacopoeia. Beijing: China Medical Pharmaceutical Science and Technology Publishing House; 2010: $39-40$

5 Shi YL, Li MF. Biological effects of toosendanin, a triterpenoid extracted from Chinese traditional medicine. Prog Neurobiol 2007; 82: 1-10

6 Isman MB. Botanical insecticides, deterrents, and repellents in modern agriculture and an increasingly regulated world. Annu Rev Entomol 2006; 51: 45-66

7 Zhao L, Huo CH, Shen LR, Yang Y, Zhang Q Shi QW. Chemical constituents of plants from the genus Melia. Chem Biodivers 2010; 7: 839-859
8 Tan QG, Luo XD. Meliaceous limonoids: chemistry and biological activities. Chem Rev 2011; 111: 7437-7522

9 MacRae WD, Towers GHN. Biological activities of lignans. Phytochemistry 1984; $23: 1207-1220$

10 Ríos JL, Giner RM, Prieto JM. New findings on bioactivity of lignans. Stud Nat Prod Chem 2002; 26: 183-292

11 Konoshima T, Takasaki M. Anti-tumor-promoting activities (cancer chemopreventive activities) of natural products. Stud Nat Prod Chem 2000; 24: 215-267

12 Li XB, Yang ZX, Yang L, Chen XL, Zhang K, Yang Q Wu YM, Liu SB, Tao KS, Zhao MG. Neuroprotective effects of flax lignan against NMDA-induced neurotoxicity in vitro. CNS Neurosci Ther 2012; 18: 927-933

13 Jang EY, Park KA, Lee JR, Yang CH, Hwang M. Protective effect of sauchinone on methamphetamine-induced neurotoxicity in mice. J Pharmacol Sci 2012; 118: 531-536

$14 \mathrm{Kim}$ YC. Neuroprotective phenolics in medicinal plants. Arch Pharm Res 2010; 33: 1611-1632

15 Cui HS, Kim MR, Sok DE. Protection by petaslignolide A, a major neuroprotective compound in the butanol extract of Petasites japonicus leaves, against oxidative damage in the brains of mice challenged with kainic acid. J Agric Food Chem 2005; 53: 8526-8532

16 Bustamante-García R, Lira-Rocha AS, Espejo-González O, Gómez-Martínez $A E$, Picazo $O$. Anxiolytic-like effects of a new $1-N$ substituted analog of melatonin in pinealectomized rats. Prog Neuropsychopharmacol Biol Psychiatry 2014; 51: 133-139

17 Chen LJ, He XB, Zhang YP, Chen XP, Lai XR, Shao JJ, Shi Y, Zhou NM. Melatonin receptor type 1 signals to extracellular signal-regulated kinase 1 and 2 via $G_{i}$ and $G_{s}$ dually coupled pathways in HEK-293 cells. Biochemistry 2014; 53: 2827-2839

18 Zlotos DP, Jockers R, Cecon E, Rivara S, Witt-Enderby PA. $\mathrm{MT}_{1}$ and $\mathrm{MT}_{2}$ melatonin receptors: ligands, models, oligomers, and therapeutic potential. J Med Chem 2014; 57: 3161-3185

19 Lee DY, Song MC, Yoo KH, Bang MH, Chung IS, Kim SH, Kim DK, Kwon BM, Jeong TS, Park MH, Baek NI. Lignans from the fruits of Cornus kousa Burg. and their cytotoxic effects on human cancer cell lines. Arch Pharm Res 2007; 30: 402-407

20 Deyama T, Ikawa T, Kitagawa S, Nishibe S. The constituents of Eucommia ulmoides Oliv. V: isolation of dihydroxydehydrodiconiferyl alcohol isomers and phenolic compounds. Chem Pharm Bull 1987; 35: 17851789

21 Deyama T, Ikawa T, Kitagawa S, Nishibe S. The constituents of Eucommia ulmoides Oliv. III. Isolation and structure of a new lignan glycoside. Chem Pharm Bull 1986; 34: 523-527

22 Kouno I, Yanagida Y, Shimono S, Shintomi M, Ito Y, Yang CS. Neolignans and a phenylpropanoid glucoside from Illicium difengpi. Phytochemistry 1993; 32: 1573-1577

23 Matsumori N, Kaneno D, Murata M, Nakamura H, Tachibana K. Stereochemical determination of acyclic structures based on carbon-proton spin-coupling constants. A method of configuration analysis for natural products. J Org Chem 1999; 64: 866-876

24 Li LY, Seeram NP. Further investigation into maple syrup yields 3 new lignans, a new phenylpropanoid, and 26 other phytochemicals. J Agric Food Chem 2011; 59: 7708-7716

25 Li X, Cao W, Shen Y, Li N, Dong XP, Wang KJ, Cheng YX. Antioxidant compounds from Rosa laevigata fruits. Food Chem 2012; 130: 575-580

26 Li YC, Kuo YH. Four new compounds, ficusal, ficusesquilignan A, B and ficusolide diacetate from the heartwood of Ficus microcarpa. Chem Pharm Bull 2000; 48: 1862-1865

27 Houghton PJ. Lignans and neolignans from Buddleja davidii. Phytochemstry $1985 ; 24: 819-826$

28 Morreel K, Ralph J, Kim H, Lu F, Goeminne G, Ralph S, Messens E, Boerjan $W$. Profiling of oligolignols reveals monolignol coupling conditions in lignifying poplar xylem. Plant Physiol 2004; 136: 3537-3549

29 Li XF, Jin HZ, Yang M, Chen G, Shen YH, Zhang WD. Chemical constituents of Rhododendron primulaeflorum. Chem Nat Compd 2010; 46: 106108

30 Jiao WH, Gao H, Zhao F, He F, Zhou GX, Yao XS. A new neolignan and a new sesterterpenoid from the stems of Picrasma quassioides Bennet. Chem Biodivers 2011; 8: 1163-1169

31 Li SM, Lundquist K, Wallis AFA. Revised structure for a neolignan from Brucea javanica. Phytochemistry 1998; 49: 2125-2128

32 Tan RX, Jakupovic J, Jia ZJ. Aromatic constituents from Vladimiria souliei. Planta Med 1990; 56: 475-477

33 Xie LH, Akao T, Hamasaki K, Deyama T, Hattori M. Biotransformation of pinoresinol diglucoside to mammalian lignans by human intestinal mi- 
croflora, and isolation of Enterococcus faecalis strain PDG-1 responsible for the transformation of (+)-pinoresinol to (+)-lariciresinol. Chem Pharm Bull 2003; 51: 508-515

34 Duan YH, Li C, Dai Y, Yao XS. A new phenylpropanediol from Sarcandra glabra (Chloranthaceae). Plant Divers Resour 2012; 34: 208-210

35 Marco I, Valhondo M, Martín-Fontecha M, Vázquez-Villa H, Río JD, Planas A, Sagredo O, Ramos JA, Torrecillas IR, Pardo L, Frechilla D, Benhamú B, López-Rodríguez $M L$. New serotonin $5-\mathrm{HT}_{1 \mathrm{~A}}$ receptor agonists with neuroprotective effect against ischemic cell damage. J Med Chem 2011; 54: 7986-7999
36 Jensen AA, Plath N, Pedersen MHF, Isberg V, Krall J, Wellendorph P, Stensbol TB, Gloriam DE, Krogsgaard-Larsen P, Frolund B. Design, synthesis, and pharmacological characterization of $\mathrm{N}$ - and $\mathrm{O}$-substituted 5,6,7,8tetrahydro-4H-isoxazolo[4,5-d]azepin-3-ol analogues: novel 5- $\mathrm{HT}_{2 \mathrm{~A}}$ / $5-\mathrm{HT}_{2 \mathrm{C}}$ receptor agonists with procognitive properties. J Med Chem 2013; 56: 1211-1227

37 Yang $C Y$, Geng $C A$, Huang XY, Wang $H$, Xu HB, Liang WJ, Ma YB, Zhang $X M$, Zhou J, Chen JJ. Noreudesmane sesquiterpenoids from the leaves of Nicotiana tabacum. Fitoterapia 2014; 96: 81-87 